\title{
(iE)
}

ФІНАНСОВО-КРЕДИТНА

I ГРОШОВА ПОЛІТИКА

УДК 336.011:364.1

JEL Classification: B 41, E 60, H 30, D 6

DOI: 10.37332/2309-1533.2020.3-4.21

Дем'янишин В.
д-р екон. наук, профес
професор кафедри фінансів ім. С. І. Юр
Горин В
канд. екон. наук, доцен
докторант кафедри фінансів ім. С. І. Юр
Тернопільський начіональний економічнй університ
ДІАЛЕКТИЧНИЙ ПІДХІД ДО ДОСЛІДЖЕННЯ ФІНАНСОВОГО
МЕХАНІЗМУ ЗАБЕЗПЕЧЕННЯ СУСПІЛЬНОГО ДОБРОБУТУ

\author{
Demianyshyn V.H., \\ dr.sc.(econ.), professor, \\ professor of S. Yuriy department of finance, \\ Horyn V.P., \\ cand.sc.(econ.), assoc. professor, \\ doctoral candidate of S. Yuriy department of finance, \\ Ternopil National Economic University
}

\section{A DIALECTICAL APPROACH TO THE STUDY OF THE FINANCIAL MECHANISM FOR ENSURING PUBLIC WELFARE}

Постановка проблеми. Крах теорії держави загального добробуту та становлення нової концепції інклюзивного розвитку супроводжувались зміною уявлень про суть суспільного добробуту та підходів до його забезпечення. За сучасними уявленнями, суспільний добробут визначають не стільки рівнем задоволення потреб людини, скільки створеними можливостями для ії розвитку і самореалізації. Зі зміною поглядів на суть суспільного добробуту виникає необхідність у модернізації фрінансового інструментарію, за допомогою якого держава впливає на економічну поведінку населення та формування його доходів, створює умови для усебічного розвитку кожного члена суспільства. Але практичним діям щодо вдосконалення фінансового механізму забезпечення суспільного добробуту має передувати модернізація науково-методологічних підходів до трактування його сутності, суспільного призначення та принципів функціонування, зокрема із застосуванням прогресивних методів наукового пізнання. В умовах поглиблення глобалізації, посилення інтеграції економічних систем, зростання впливу чинників екзогенного середовища на стабільність та розвиток суб'єктів економіки в економічній науці зростає затребуваність діалектичного підходу до наукового пізнання, що передбачає дослідження явищ та процесів у всій їх взаємозалежності та багатогранності розвитку.

Аналіз останніх досліджень $\boldsymbol{i}$ публікацій. Основу діалектичного методу, як одного $з$ найважливіших методів фрілософської методології наукового пізнання, складає застосування базових діалектичних категорій, принципів та законів. Як зазначає у Філософському енциклопедичному словнику М. Булатов, діалектичний метод визначається особливим характером співвідношення філософських категорій - їх парністю та полярністю, він представляє собою «спосіб та мистецтво розв'язання таких проблем - визначення протилежностей, аналіз та розмежування, їх синтез в деяке ціле, розкриття руху і розвитку відповідних структур, напрям, тенденції їх генезису» [10, с. 161]. У фрінансовій науці яскраві приклади застосування діалектичного методу наукового 
пізнання до розкриття фрінансової термінології представлені в опорному підручнику «Фінанси» за науковою редакцією С. Юрія і В. Федосова [11], монографіях 3. Лободіної «Бюджетний механізм: концептуальні засади та перспективи модернізації» [6], О. Тулай «Державні фінанси і сталий людський розвиток: концептуальні домінанти та діалектична єдність» [9], наукових працях Ю. Мискіна [7], Д. Рожка [8] та інших. Таким чином, використання діалектичного методу дає можливість вирішення амбівалентності результатів теоретичного та емпіричного пізнання фрінансового механізму забезпечення суспільного добробуту, їх синтез у цілісне вчення про теоретичні та практичні аспекти його функціонування.

Постановка завдання. Мета статті передбачає наукове обґрунтування теоретикометодологічних засад фінансового механізму забезпечення суспільного добробуту із застосуванням діалектичного методу наукового пізнання.

Виклад основного матеріалу дослідження. Процес дослідження фрінансового механізму забезпечення суспільного добробуту за діалектичним методом передбачає застосування відповідного інструментарію, що об'єднує принципи, методи та закони діалектики. До основних законів діалектики належать закон переходу кількісних змін у якісні; закон єдності та боротьби протилежностей; закон заперечення заперечень.

Зміст закону переходу кількісних змін у якісні полягає у тому, що поступове нагромадження кількісних змін на певних етапах процесу спричиняє стрибкоподібний перехід до істотних якісних змін, трансформації попередньої якості у нову. Закон розкриває найбільш загальний алгоритм розвитку, його знання слугує засобом осмислення й перетворення дійсності [5, с. 6].

В основу цього діалектичного закону покладене застосування тріоди фрілософських понять «кількість», «якість», «міра», застосування яких дає змогу відобразити логіку розвитку фрінансового механізму забезпечення суспільного добробуту. Якість $€$ сукупністю іманентних ознак явища, втрата яких призведе до зміни його сутності. Ці ознаки відрізняють явище з-поміж інших. Кількість $\epsilon$ зовнішньою ознакою явища, що вимірює зміни його властивостей. Динамічна тотожність кількості та якості визначає міру, що має об'єктивний характер та загальне значення.

Відносно фінансового механізму забезпечення суспільного добробуту, фрілософрська категорія якості визначає таку його модель, що в умовах наявного рівня економічного розвитку та суспільного консенсусу щодо міри задоволення потреб суспільства та необхідних умов для його розвитку дає можливість максимізувати рівень суспільного добробуту. Категорія якості, з одного боку, характеризує сукупність найбільш суттєвих, іманентних ознак цього механізму, що вирізняють його 3-поміж інших економічних механізмів, з іншого боку, вона вказує на оптимальну в наявних умовах модель фрінансового забезпечення та регулювання процесу мобілізації та спрямування фінансових ресурсів на задоволення різноманітних потреб суспільства та створення умов для його розвитку, що в сукупності формують уявлення про рівень суспільного добробуту. Кількість, у застосуванні до фрінансового механізму забезпечення суспільного добробуту, $\epsilon$ відображенням реально діючої моделі фрінансового механізму, кількісних параметрів застосування методів, фрорм, важелів та інструментів для формування і використання фрінансових ресурсів з метою підвищення суспільного добробуту.

У відповідності до основного принципу діалектичної логіки «тотожності мислення і буття», між кількісною і якісною сторонами фрінансового механізму забезпечення суспільного добробуту є тісний динамічний взаємозв'язок, адже вони, хоча й відмінні між собою, однак здатні трансформуватись одна в одну. Якість переходить у кількість тому, що в силу дії різних чинників зовнішнього та внутрішнього характеру реальна модель фінансового механізму забезпечення суспільного добробуту відхиляється від ії теоретичної моделі, хоча й зберігає її істотні ознаки. Водночас, кількісні зміни спричиняють трансформацію якості, оскільки накопичені у реальному фінансовому механізмі стійкі відмінності від його теоретичної моделі, нові ознаки, характеристики, проблемні моменти зрештою обумовлюють необхідність трансформації самої теоретичної моделі фрінансового механізму забезпечення суспільного добробуту, тобто становлення нової якості. Єдність кількісного та якісного боків фінансового механізму забезпечення суспільного добробуту постає як міра, певне співвідношення його кількісних та якісних характеристик (рис. 1).

Оригінальне трактування законів діалектики та бачення їх застосування у наукових дослідженнях 3 проблематики фінансів запропоноване Ю. Мискіним [7]. На його думку, амбівалентність діалектичних законів справляє відповідний вплив на самі досліджувані за їх допомогою явища. Термін «амбівалентність» (від лат. аmbo - обидва, valentia - сила) увійшов у науковий обіг психології на початку XX ст. у зв'язку із вивченням соціальних установок, в подальшому він знайшов застосування в інших науках гуманітарного циклу. За визначення довідкової літератури, амбівалентність - це суперечливе, взаємовиключне ставлення до об'єкта, переживання відносно нього водночас негативних та позитивних оцінок [1, с. 34]. На думку Ю. Мискіна, поширене формулювання діалектичного закону «взаємного переходу кількісних та якісних змін» звужує логіку наукового мислення до амбівалентного підходу, за яким розвиток характеризують тільки дві ознаки якість та кількість. У такій філософській системі координат повністю ігнорується категорія порядку. Між тим, на думку Ю. Мискіна, якість є, по суті, похідною від кількості та порядку, адже кількісні та 
порядкові зміни спричиняють якісні трансформації об'єкта, в свою чергу якісні характеристики отримують своє відображення у кількісних і порядкових трансформаціях. Розвиток трактується ним як результат логічної послідовності причинно-наслідкової взаємодії якісних, кількісних та порядкових параметрів [7, с. 94].

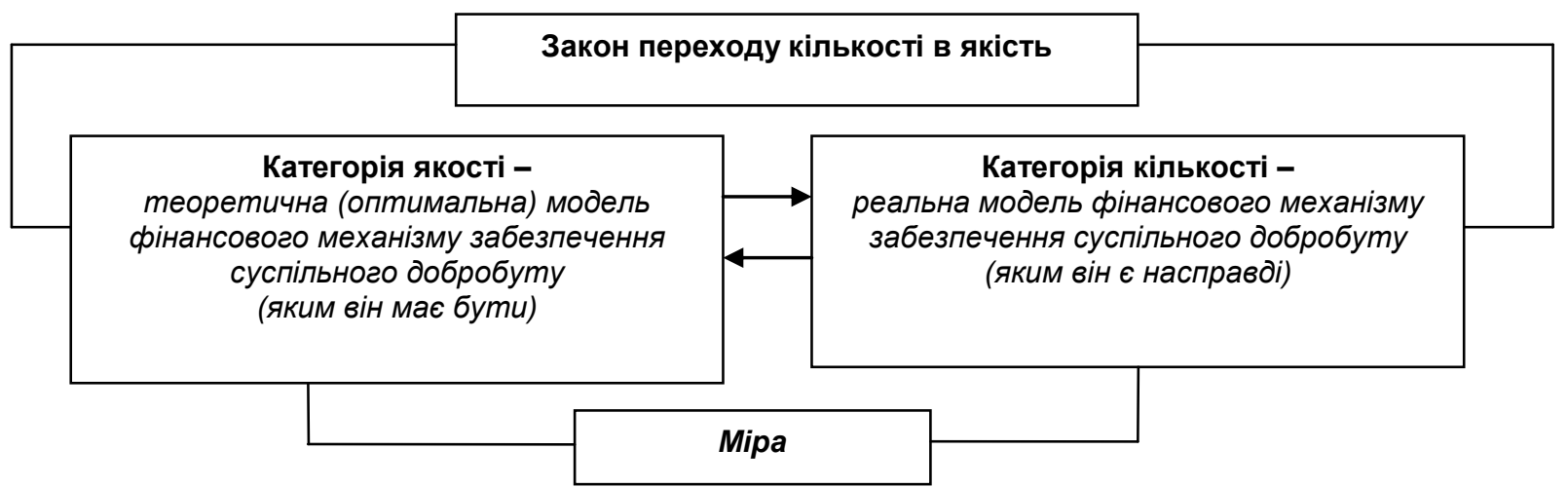

Рис. 1. Взаємозв'язок між категоріями кількості та якості у трактуванні фінансового механізму забезпечення суспільного добробуту

Джерело: складено авторами за [3, с. 35]

Нове формулювання діалектичного закону переходу кількісних змін у якісні як послідовності причинно-наслідкової взаємодії якісних, кількісних та порядкових параметрів отримує підтвердження у дослідженні фінансового механізму забезпечення суспільного добробуту. На наш погляд, розкриття його потенціалу та ефективності щодо впливу на рівень суспільного добробуту визначається не лише кількісними змінами параметрів його складових (обсягів фрінансування, кредитування, ставок фріскальних платежів, бази оподаткування та ін.), але й структурною композицією їх застосування (поєднання різних методів, форм, важелів, інструментів фрінансового механізму у відповідності до існуючих соціально-економічних реалій). Відтак, цілком справедливо, що в основу трансформації теоретичної моделі фрінансового механізму забезпечення суспільного добробуту (категорія якості) лягають зміни у реальних параметрах елементів самого механізму (категорія кількості) і підходах до їх комплексного застосування (категорія порядку) (рис. 2).

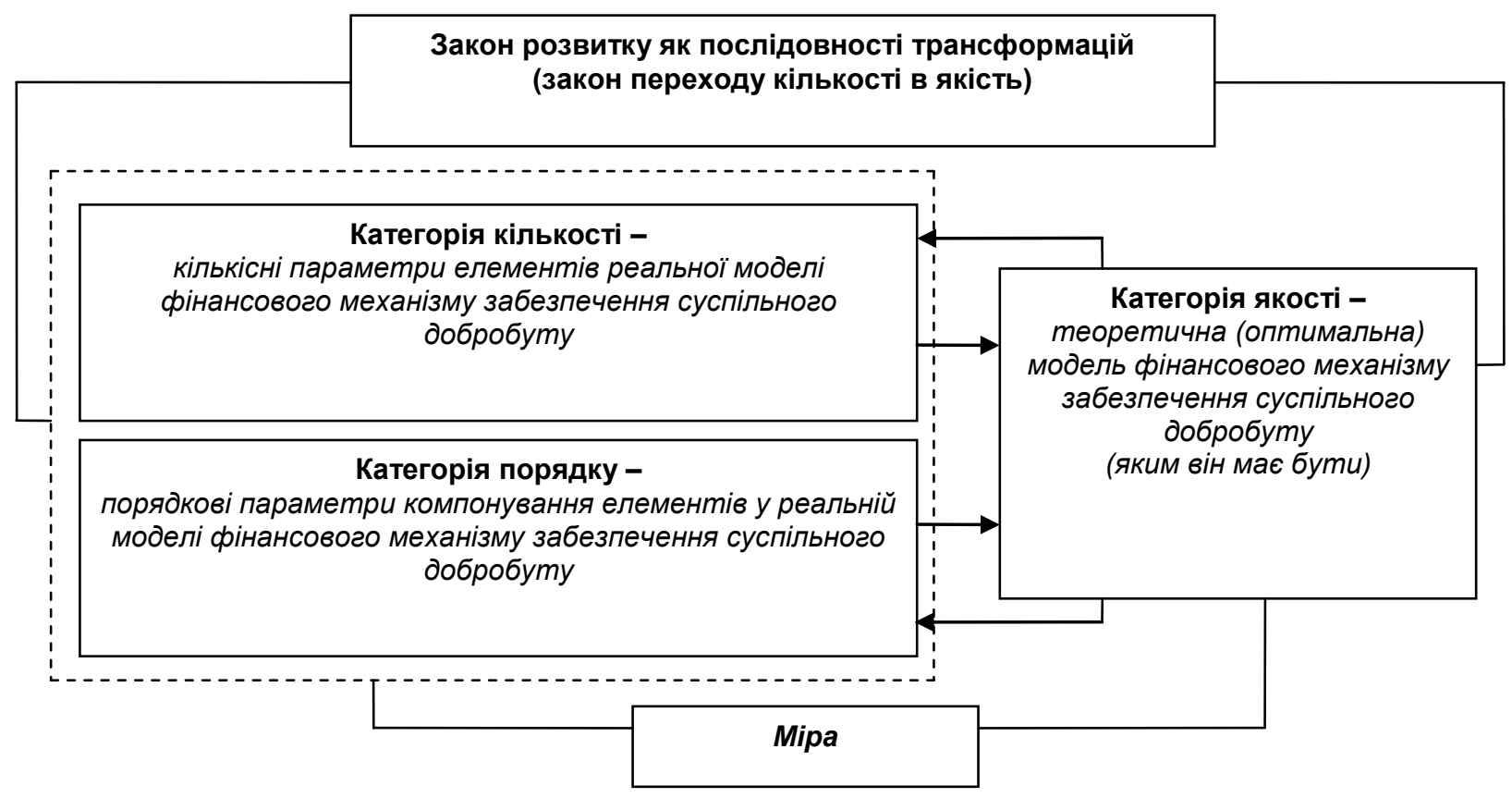

Рис. 2. Взаємозв'язок між категоріями кількості, порядку та якості у трактуванні фінансового механізму забезпечення суспільного добробуту

Джерело: складено авторами за [7, с. 93]

В рамках застосування діалектичного методу наукового пізнання важливе значення має закон єдності та боротьби протилежностей, за яким кожне явище характеризується внутрішньо притаманними йому суперечностями. Внутрішня боротьба цих суперечностей $\epsilon$ джерелом 
саморозвитку явища. Суперечності представляють собою такі характеристики, ознаки, тенденції у трансформації об'єкта, які є водночас взаємопроникними, взаємопов'язаними та взаємовиключними. Традиційно, приклади реалізації закону єдності та боротьби протилежностей у фінансовій практиці пов'язують із антагонізмом інтересів держави, приватного сектору економіки у царині сплати фіскальних платежів, що лежать в основі розвитку публічних фрінансів [5, с. 6]. Інтерпретуючи дію закону єдності та боротьби протилежностей у рамках дослідження державних фінансів, О. Тулай зазначає, що: по-перше, державні фрінанси та приватний сектор взаємопов'язані між собою; по-друге, вони взаємовиключають одне одного; по-третє, вони є взаємопроникними [9, с. 161]. У єдності цих протилежностей, у гармонізації інтересів, цілей та дій лежить шлях до розвитку.

Але, наскільки об'єктивними є ключові тези діалектичного закону єдності та боротьби протилежностей у реальній дійсності, чи завжди об'єкт пізнання характеризується наявністю діаметрально протилежних ознак чи тенденцій? Розкриваючи амбівалентність трактування діалектичного закону єдності та боротьби протилежностей, А. Мискін стверджує, що у випадку, якщо певна система чи процес визначається двома та більше характеристиками, вони не обов'язково мають бути парними протилежностями, а можуть розглядатись як різні якості об'єкта. Недоцільно абсолютизувати і боротьбу протилежностей, адже вона може передбачати повне знищення системи чи процесу, на противагу якісним змінам та розвитку [7, с. 92].

Екстраполюючи ці умовиводи на сучасну дійсність, переконуємось у їх об'єктивності. Чи настільки у сучасному світі $€$ антагоністичними інтереси сторін в рамках фінансових відносин? Для прикладу, відповідно до положень теорії фіскального обміну, між платниками податків і державою існує взаємовигідний обмін за схемою «податки-блага». Тобто, можна говорити не про боротьбу, а про взаємодію інтересів сторін у рамках процесів фіску. В сучасній соціально-орієнтованій економіці ринкова вартість суб'єкта господарювання, перспективи його зростання залежать не лише від фрінансових результатів господарської діяльності (втілення особистих інтересів), але й від того, чи відчуває компанія суспільну відповідальність у взаєминах із державою і суспільством, чи реалізує програму корпоративної соціальної відповідальності, підтримки соціальних проектів (втілення суспільних інтересів). На наш погляд, умовою стабільного розвитку суб'єкта господарювання (реалізація власних інтересів) в сучасних умовах $\epsilon$ сприятливе середовище, що передбачає відповідне ставлення з боку держави, відсутність соціальних конфрліктів, відповідальний імідж у населення. Таким чином, теза про боротьбу протилежностей як причину та умову розвитку явищ та процесів об'єктивної дійсності значною мірою втратила об'єктивність. Більш прийнятно розглядати зміст цього діалектичного закону як розвиток об'єкта, що реалізується на основі постійного вдосконалення взаємодії його різних якостей.

Стосовно фінансового механізму забезпечення суспільного добробуту, його реально існуючу модель, відповідно до нової інтерпретації закону єдності та боротьби протилежностей, доцільно розглядати як результат взаємодії інтересів усіх суб'єктів економіки, задіяних у процесі фрормування параметрів суспільного добробуту. Через узгодження інтересів держави, відповідальної перед суспільством за задоволення його потреб, приватного сектору економіки, який прагне комфортних умов діяльності та фрінансового результату, а також домогосподарств, що безпосередньо зацікавлені у всебічному задоволенні своїх потреб, а також з урахуванням чинників середовища формування відбувається визначення конфігурації і параметрів застосування усіх складових фінансового механізму - поєднання його ключових методів, форм, важелів та інструментів впливу фрінансів на процеси фрормування суспільного добробуту (рис. 3).

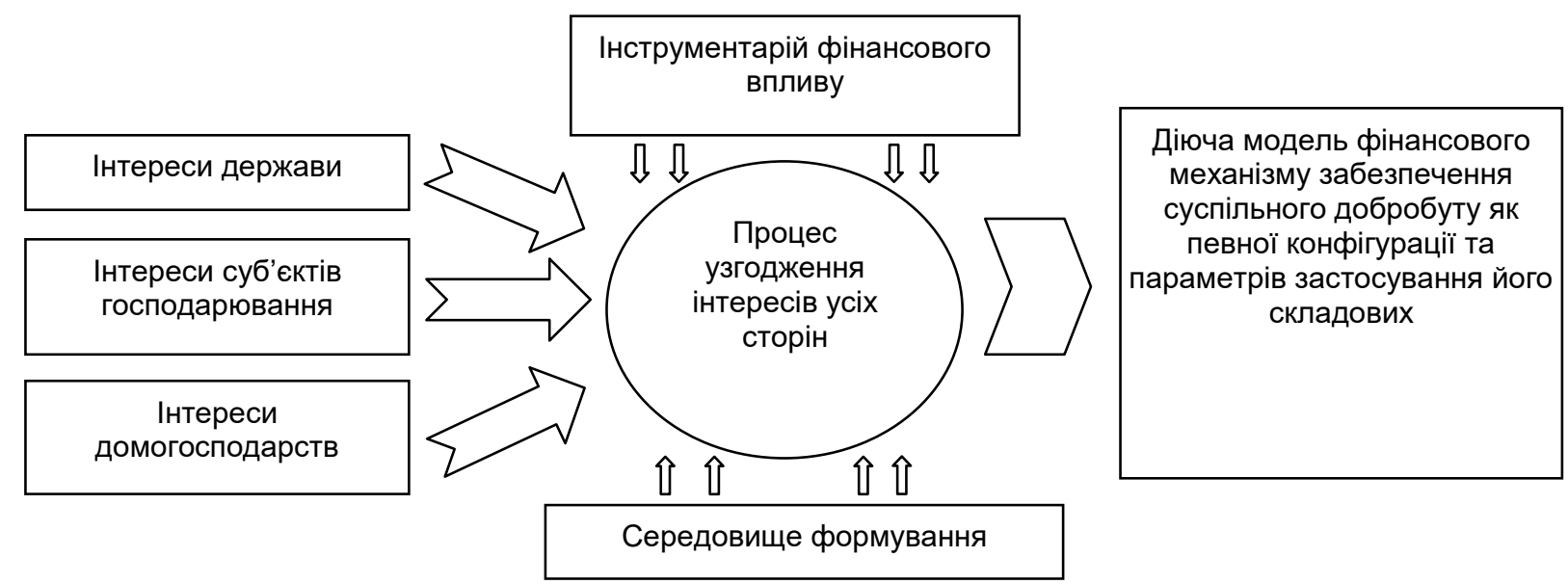

\footnotetext{
Рис. 3. Логіка формування фінансового механізму забезпечення суспільного добробуту за законом єдності та боротьби протилежностей

Джерело: складено авторами самостійно
} 
У законі заперечення заперечень, що є одним із тріади найважливіших законів діалектичного методу, відображене наступництво, спадковість, зв'язок старого із новим, повторюваність окремих рис консеквентних стадій розвитку, принципові особливості процесу руху. Основна ідея цього закону діалектики полягає у послідовності, спіральності розвитку, коли на кожному витку спіралі розвитку спостерігається повторення відомих, але оновлених характерних рис об'єкта, із застосування нових елементів, розвиток від нижчого до вищого, від старого до нового, від одного заперечення до іншого. Спрощено його суть можна окреслити висловом «нове - це давно забуте старе». Базуючись на такому ідейному підґрунті, діалектичний закон заперечення заперечень дає змогу прослідкувати розвиток у часі, визначити його напрями та траєкторії для можливості впливати на нього [5, с. 7].

На думку Ю. Мискіна, інтерпретуючи суть заперечення заперечень як поступовий та спадковий розвиток, відповідний закон діалектичного методу упускає важливі моменти: по-перше, перехід від одного заперечення до іншого засвідчує не лише новий етап розвитку, але й руйнацію попереднього; по-друге, саме формулювання «заперечення заперечень» формує переконання у тому, що нове заперечення неостаточне, недосконале, бо його змінить нове заперечення, що має наслідком стримування творчої ініціативи людини [7, с. 93-94]. Більш логічною $є$ інтерпретація цього закону через послідовність трансформацій на основі зміни конфігурації взаємодії його різних якостей під дією зовнішніх та внутрішніх чинників.

Накладаючи ідейний базис діалектичного методу заперечення заперечень на дослідження фрінансового механізму забезпечення суспільного добробуту, слід зауважити, що його розвиток має перманентний характер, що пояснюється мінливістю зовнішнього середовища його фрормування, зміною уявлень про суть суспільного добробуту, ефективні способи й роль кожного із суб'єктів економіки у його забезпеченні. Наприклад, в період превалювання кейнсіанських підходів до регулювання економіки, у фінансовому інструментарії забезпечення суспільного добробуту мали пріоритет різні форми та інструменти бюджетного фінансування матеріального забезпечення різних верств населення, надання суспільних послуг. Однак, криза соціальної держави спричинила повернення до неокласичних підходів до регулювання економіки, в тому числі у фінансовій сфері. Це виявилось у посиленні ролі інструментів фінансового регулювання, в тому числі й щодо процесів забезпечення суспільного добробуту, а також зміни підходів до бюджетного фінансування, впровадження непрямих схем розподілу бюджетних коштів, що містять ознаки змагальності за отримання фінансування. В теперішній час з утвердженням парадигми інклюзивного розвитку, в складі фрінансового механізму посилюється роль фінансових інструментів, покликаних забезпечити стійке зростання суспільного добробуту, однак на певній основі - через максимальне включення усіх суспільних верств до продуктивної зайнятості, розширення можливостей для втілення підприємницьких ініціатив, зростання доступності суспільних послуг.

Поряд з основними законами, важливу роль у застосуванні діалектичного методу пізнання відіграють категорії діалектики - поняття, що відображають найбільш загальні та суттєві властивості, зв'язки, відношення явищ і предметів реальної дійсності. Відповідно до закону єдності і боротьби протилежностей у його синергетичній інтерпретації, наукове дослідження фрінансового механізму забезпечення потребує застосування полярних і, водночас, взаємодоповнюючих фрілософських категорій «сутність» та «явище», «форма» і зміст».

На думку О. Тулай, категорії сутності та явища характеризують певні відношення в дійсності (онтологічний аспект); зв'язок об'єкта та суб'єкта у процесі пізнання (гносеологічний аспект); відповідні відношення у людському мисленні (логічний аспект) [9, с. 162]. У взаємодії сутності і явища виявляється зв'язок між раціональним та емпіричним знанням, оскільки знання про сутність має об'єктивний характер лише у випадку, якщо воно є результатом синтезу мислення та емпіричного експерименту. Розкриття сутності означає з'ясування глибинних причин та принципів існування об'єкта, його розвитку. Натомість, явище характеризує те, як об'єкт фрункціонує в об'єктивній дійсності.

Сутність характеризує внутрішнє наповнення об'єкта, їх природу, явище - це зовнішній вияв сутності, форма її прояву. Явище без сутності існувати не може, і зворотно, чи можна пізнати сутність об'єкта, якщо він не має прояву в об'єктивній дійсності. Таким чином, сутність і явище представляють собою суперечні, але взаємодоповнюючі характеристики об'єкта пізнання, що доповнюють одна одну.

В сучасній науковій літературі наявний широкий спектр поглядів на трактування базового поняття «фінансовий механізм»: як сукупність фрінансових методів, форм, інструментів та важелів впливу на соціально-економічний розвиток; сукупність конкретних фрорм та методів забезпечення розподільчих та перерозподільчих відносин; сукупність економіко-організаційних та правових фрорм і методів управління фрінансовою діяльністю тощо. Кожен із цих підходів має право на існування, розкриває певні особливості фрінансового механізму, що сукупно характеризують його сутність як складного економічного поняття.

Фінансовий механізм забезпечення суспільного добробуту $є$ різновидом фрінансового механізму, що має спільні з ним риси, але володіє також певними особливостями, що 
характеризують його суспільне призначення. Загальними характеристиками фрінансового механізму забезпечення суспільного добробуту, що поєднують його з іншими різновидами фінансового механізму, $є$ те, що вони оперують вартісними нормами, нормативами, показниками; передбачають застосування фрінансових методів, важелів, інструментів; призначені для впливу на процеси розподілу та перерозподілу фрінансових ресурсів; змінюються та вдосконалюються із розвитком ринкових відносин.

Ключовими специфічними рисами фрінансового механізму забезпечення суспільного добробуту $\epsilon$ те, що використання усіх його складових спрямоване на забезпечення цілеспрямованого впливу держави на формування фінансових ресурсів та їх спрямування на цілі, що визначають стан суспільного добробуту; трансформація цього механізму відбувається не тільки під впливом розвитку ринкових відносин, але й із зміною суспільного уявлення про стан добробуту, підходи до його забезпечення та розподіл сфер відповідальності між основними суб'єктами економіки у цих процесах; він втілює у собі способи практичної реалізації консенсусу між суспільством, державою та бізнесом стосовно рівня забезпечення потреб населення в економічних благах та створення умов для розвитку і самореалізації кожного члена суспільства.

Таким чином, за сутністю фінансовий механізм забезпечення суспільного добробуту представляє собою засіб впливу на процес формування та використання фінансових ресурсів для задоволення потреб суспільства та створення умов для його розвитку, що характеризують стан добробуту. Як явище реальної дійсності, фінансовий механізм забезпечення суспільного добробуту виявляється через регулюючий вплив на процеси формування і використання фрінансових ресурсів на забезпечення суспільного добробуту, що здійснюється відповідно до певних формальних $\mathrm{i}$ неформальних правил організації.

Вияв сутності фрінансового механізму забезпечення суспільного добробуту як об'єктивного економічного поняття відбувається за допомогою функцій, які він виконує. Відзначимо, що, на відміну від функцій власне фінансів, функції фрінансового механізму практично не представлені у сучасних наукових працях з фінансової проблематики. Частина науковців дотримується позиції, що через фрінансовий механізм отримують своє вираження функції фрінансової політики. Окремі науковці, зокрема, Л. Катан та О. Добровольська, наділять фрінансовий механізм переліком фрункцій: відтворювальною, мотиваційною, регулюючою, раціоналізації, перерозподільчою, контрольною [4, с. 269-272]. На наш погляд, вказані функції не є об'єктивним виявом сутності фінансового механізму як економічного поняття, а характеризують функціональне призначення окремих його складових. Функція, відображаючи об'єктивні властивості економічного поняття, виявляє свою дію впродовж усього періоду його існування. Зважаючи на це, визначені Л. Катан та О. Добровольською функції фрінансового механізму не можуть бути такими в принципі. Для прикладу, чи можна охарактеризувати застосування фрінансових санкцій як прояв мотиваційної функції фрінансового механізму, або ж чи у всіх випадках застосування інструментарію фрінансового механізму є прояв раціоналізації. Подібні контраргументи можна підібрати і щодо інших пропонованих функцій фрінансового механізму.

Більш прийнятною у цьому ракурсі $€$ позиція О. Василика, який розглядає бюджетний механізм, наділяючи його функціями бюджетного забезпечення та бюджетного регулювання. Між тим, науковець визнає, що ці функції є повною теоретичною абстракцією, оскільки бюджетне забезпечення може одночасно виконувати функцію бюджетного регулювання, так само як регулювання може здійснювати функцію бюджетного забезпечення [2, с. 45]. Оскільки бюджетний механізм є складовою фінансового механізму, то за правилом «частина - ціле», відповідними функціями можна наділити і сам фрінансовий механізм. Отож, на наш погляд, фінансовий механізм забезпечення суспільного добробуту виконує функції фрінансового забезпечення і фрінансового регулювання, які водночас, $є$ основними методами впливу на процес формування і використання фрінансових ресурсів для забезпечення суспільного добробуту. Застосування регуляторних інструментів, таких як дотації, субсидії, хоч і належить до царини фінансового регулювання, фактично можна розглядати як елемент фрінансового забезпечення, але зі стимулюючим підтекстом. 3 іншого боку, у різноманітних інструментах фрінансового забезпечення також можна прослідкувати елементи регулювання.

Вдалою $€$ думка О. Василика, що кількісний та якісний бік бюджетного механізму визначаються тим, яка величина бюджетних ресурсів зосереджується і витрачається на відповідних рівнях управління, а також яка технологія їх зосередження і витрачання. Очевидно, успішність функціонування фрінансового механізму забезпечення суспільного добробуту залежить не тільки від обсягів фінансових ресурсів, які надходять з цією метою від усіх суб'єктів економіки, але й від того, які форми, важелі та інструменти та в якій комбінації при цьому використовують. Відповідно до положень парадигми інклюзивного розвитку, на сьогодні для фрінансового забезпечення суспільного добробуту характерна тенденція до звуження масштабів зовнішнього фінансування і посилення ролі самофрінансування населенням власного добробуту. Водночас, з інструментів зовнішнього, зокрема бюджетного фрінансування, пріоритет отримують ті з них, які передбачають елементи змагальності при розподілі коштів. 
Функція фрінансового регулювання фрінансового механізму забезпечення суспільного добробуту полягає у застосуванні фінансового інструментарію для коригування об'ємно-структурних параметрів фінансових ресурсів, які суб'єкти економіки направляють на забезпечення суспільного добробуту. При цьому, в рамках регулювання можуть застосуватись як експансивні (стимулюючі), так і рестриктивні (стримуючі) фрінансові інструменти. Так, встановлення пільгових ставок непрямих податків на товари першої потреби покликане забезпечити їх доступність для широких суспільних верств. Або, навпаки, підвищення рівня податкового навантаження на шкідливі для здоров'я товари покликане знизити їх споживання через ціновий механізм.

Важливою ознакою будь-якого об'єктивного явища чи процесу є його зміст, що характеризує сукупність всіх його елементів, єдність їх властивостей, внутрішніх процесів, зв'язків, суперечностей і тенденцій розвитку. Форма представляє собою спосіб вияву змісту, відносно стійку визначеність зв'язку та взаємодії його елементів [5, с. 7]. Це внутрішня та зовнішня організація змісту, спосіб його існування, що має певну визначність, стабільність, самостійність. Зміст та форма єдині, адже не може існувати безформного змісту і форми, позбавленої змісту. Форма підпорядкована змісту, $\epsilon$ його внутрішнім зв'язком та порядком. Вона може відставати від трансформації змісту, що виявляється у виникненні суперечностей між ними. Із наростанням глибини невідповідності форми змістові виникає необхідність руйнації застарілої форми та виникнення нової, такої, що відповідає новому змісту. Так, у фінансовому забезпеченні суспільного добробуту застосовують різні фрорми фінансування. Якщо вони не відповідають вимогам часу, їх ефективність є недостатньою, вони гальмують можливість реалізації змісту фрінансового забезпечення і потребують оновлення. Водночас, поява нових фрорм фрінансування спричиняє певні трансформації самого змісту фрінансового забезпечення.

За економічним змістом фрінансовий механізм забезпечення суспільного добробуту $\epsilon$ сукупністю методів, форм, важелів й інструментів, застосування яких забезпечує кількісні та якісні зміни процесу формування та використання фінансових ресурсів на забезпечення суспільного добробуту. В сукупності ці елементи складають фрункціональну підсистему, яка характеризує призначення фрінансового механізму. Втім, реалізація потенціалу фрунцціональної підсистеми неможлива без існування забезпечувальної підсистеми фрінансового механізму, яку утворюють нормативно-правове, організаційне, інформаційне забезпечення.

При фрункціонуванні фрінансового механізму забезпечення суспільного добробуту його структурні елементи утворюють різноманітні форми. Формами фінансового механізму $\epsilon$ способи формування та використання фрінансових ресурсів. В рамках фінансового механізму забезпечення суспільного добробуту отримують застосування різні форми внутрішнього, зовнішнього фінансування, а також змішаного фрінансування. У період планової економіки найважливішою фрормою фрінансового забезпечення суспільного добробуту виступало бюджетне фрінансування, під яким в науковій літературі розуміють надання грошових коштів з бюджету на виконання заходів, передбачених бюджетом. 3 переходом до ринкової економіки у фрінансовому забезпеченні суспільного добробуту все більшого значення отримують інші фрорми зовнішнього фрінансування, зокрема фінансування за проектами корпоративної соціальної відповідальності, а також фінансування за благодійними проектами. У зв'язку із динамічним зростанням масштабів трудової міграції в теперішній час підвищується роль такої форми внутрішнього фрінансування суспільного добробуту, як фінансування за міжсімейними трансфертами. Винятково важливу роль у забезпеченні добробуту непрацездатної частини населення відіграє така форма змішаного фрінансування, як страхування. В теперішній час через різні види соціального страхування забезпечується матеріальний добробут майже третини населення України, різні види виплат за соціальним страхуванням (пенсії, допомоги та ін.) забезпечують фрормування майже чверті сукупних грошових доходів громадян.

У практиці фінансового регулювання суспільного добробуту отримують застосування дві його форми - фріскально-бюджетне та грошово-кредитне (або монетарне). Перша форма фрінансового регулювання передбачає використання фріскально-бюджетного інструментарію (податків, трансфертів) для впливу на фрормування і використання фінансових ресурсів на забезпечення суспільного добробуту. В умовах ринку провідна роль серед інструментів регулювання належить податкам. Через зміни в ставках податків, коригування податкової бази, кола платників, податкові пільги держава може суттєво впливати на обсяг і спрямування коштів, що направляються усіма суб'єктами економіки на цілі, які визначають параметри суспільного добробуту. Не менше значення серед інструментів фріскально-бюджетного регулювання мають трансферти, зокрема бюджетні дотації та субсидії. Не зважаючи на те, що за фрормою прояву ці види бюджетних трансфертів подібні до бюджетного фрінансування, вони мають інше призначення, яке полягає у стимулюванні реципієнта до певних дій у бажаному напрямку, мотивації його до перерозподілу власних фінансових ресурсів на користь напрямку використання, що впливає на рівень суспільного добробуту. Зокрема, фрінансова підтримка малого підприємництва через часткове покриття зобов'язань зі сплати процентів за банківськими кредитами покликана сприяти розвитку 
підприємництва і вирішення за рахунок цього проблеми безробіття та низького рівня життя населення. Державні і місцеві програми співфінансування проектів енергозбереження для фрізичних осіб спрямовані на підтримку зусиль громадян щодо підвищення енергоефективності будівель, зменшення витрат енергоресурсів, підвищення комфорту життя, що $є$ важливою характеристикою добробуту.

Інша форма фрінансового регулювання суспільного добробуту - грошово-кредитне регулювання - полягає у використанні монетарних інструментів для впливу на пропозицію грошових ресурсів на ринку, вартість кредитів, рівень інфляції, валютний курс. Проводячи політику експансії, грошово-кредитний регулятор стимулює збільшення пропозиції кредитних ресурсів на ринку, їх здешевлення, що сприяє активізації економічної діяльності, зростанню рівня зайнятості та доходів населення. Однак, негативним моментом такої політики є підвищення темпів інфрляції. Рестрикційна політика спрямована на обмеження економічної активності задля зниження темпів інфрляції. Не зважаючи на те, що монетарна політика призначена перш за все для регулювання темпів інфляції та економічного зростання, ії вплив на рівень суспільного добробуту очевидний. Регулюючи рівень процентних ставок за активними і пасивними операціями фінансово-кредитних установ, Національний банк України визначає траєкторію зміни депозитів фізичних і юридичних осіб, обсяги кредитування, таким чином впливає на показники доходів населення від фінансового інвестування, а також можливості домогосподарств з розширення споживання за рахунок кредитів.

Висновки 3 проведеного дослідження. Застосування діалектичного методу наукового пізнання дало можливість розглянути фрінансовий механізм забезпечення суспільного добробуту у його багатогранності й взаємозалежності із зовнішнім середовищем. На підставі нового прочитання базових законів діалектики, що усуває їх амбівалентність, охарактеризовано фрінансовий механізм забезпечення суспільного добробуту з таких позицій: послідовності причинно-наслідкової взаємодії його якісних, кількісних та порядкових параметрів; результату взаємодії інтересів усіх суб'єктів економіки, задіяних у процесі формування параметрів суспільного добробуту, що отримує вираження у конфігурації і параметрах застосування складових фінансового механізму; послідовності трансформацій фрінансового механізму забезпечення суспільного добробуту на основі зміни конфігурації взаємодії його різних якостей під дією зовнішніх та внутрішніх чинників. Застосування базових категорій діалектики дало змогу розкрити фінансовий механізм забезпечення суспільного добробуту за сутністю, як явище, за формою та змістом, а також виокремити його функції.

\section{Література}

1. Блейхер В. М., Крук И. В. Толковый словарь психиатрических терминов: в 2-х т. Ростов-наДону : Феникс, 1996. Т. 1.480 с.

2. Василик О., Павлюк К. Бюджетна система : підручник. Київ : Центр навчальної літератури, 2004. 544 C.

3. Дем'янишин В. Г. Теоретична концептуалізація $i$ практична реалізація бюджетної доктрини України : монографія. Тернопіль : ТНЕУ, 2008. 496 с.

4. Катан Л., Добровольська О. Фінансово-кредитне державне регулювання АПК в структурі функцій фінансового механізму. Взаємодія банків та інших фінансових установ з підприємствами: теорія, методика і практична реальність: монографрія / за заг. ред. Л. Катан та Н. Демчук. Дніпро : Пороги, 2018. С. 269-282.

5. Лободіна 3. Діалектичний та інституціональний підходи до дослідження бюджетного механізму соціально-економічного розвитку держави. Evropský časopis ekonomiky a managementu. 2018. Svazek 4. 5. vydání S. 5-11.

6. Лободіна 3. М. Бюджетний механізм: концептуальні засади та перспективи модернізації : монографрія. Тернопіль : ТНЕУ, 2018. 411 с.

7. Мискін Ю. Діалектика фріскальної соціології: від амбівалентності до синергетики. Облік $i$ фінанси. 2018. № 2(80). С. 89-95.

8. Рожко Д. Теоретичні засади та проблематика визначення сутності бюджету. Вісник Київського національного університету імені Тараса Шевченка. Серія: Економіка. 2009. Вип. 110. C. 54-56.

9. Тулай О. І. Державні фрінанси і сталий людський розвиток: концептуальні домінанти та діалектична єдність : монографія. Тернопіль : Економічна думка, 2016. 414 с.

10. Філософський енциклопедичний словник / гол. ред. кол. В.І.Шинкарук; наук. ред. Л. В. Озадовська, Н. П. Поліщук. Київ : Абрис, 2002. 751 с.

11. Фінанси : підручник / Юрій С. І. та ін.; за ред. С. І. Юрія, В. М. Федосова. 2-ге вид., перероб. і доп. Київ : Знання, 2012. 687 с. 


\section{References}

1. Bleykher, V.M. and Kruk, I.V. (1996), Tolkovyi slovar psikhiatricheskikh terminov: $v$ 2-kh $t$. [Explanatory Dictionary of Psychiatric Terms: in 2 Vols.), Feniks, Rostov-na-Donu, Russia, Vol. 1, 480 p.

2. Vasylyk, O. and Pavliuk, K. (2004), Biudzhetna systema [Budget system], textbook, Tsentr navchalnoi literatury, Kyiv, Ukraine, 544 p.

3. Demianyshyn, V.H. (2008), Teoretychna kontseptualizatsiia i praktychna realizatsiia biudzhetnoi doktryny Ukrainy [Theoretical conceptualization and practical implementation of budget doctrine for Ukraine], monograph, TNEU, Ternopil, Ukraine, $496 \mathrm{p}$.

4. Katan, L. and Dobrovolska, O. (2018), "Financial and credit state regulation of agro-industrial complex in the structure of the financial mechanism functions". In: Katan, L. and Demchuk, N. (Eds.), Vzaiemodiia bankiv ta inshykh finansovykh ustanov z pidpryiemstvamy: teoriia, metodyka $i$ praktychna realnist [Interaction of banks and other financial institutions with enterprises: theory, methods and practical reality], monograph, Porohy, Dnipro, Ukraine, pp. 269-282.

5. Lobodina, Z. (2018), "Dialectical and institutional approaches to the study of the budget mechanism of social and economic development of the state", European journal of economics and management, Vol. 4, Issue 5, pp. 5-11.

6. Lobodina, Z.M. (2018), Biudzhetnyi mekhanizm: kontseptualni zasady ta perspektyvy modernizatsii [Budget mechanism: conceptual principles and prospects of modernization], monograph, TNEU, Ternopil, Ukraine, $411 \mathrm{p}$.

7. Myskin, Yu. (2018), "Dialectics of fiscal sociology: from ambivalence to synergetics", Oblik $i$ finansy, no. 2(80), pp. 89-95

8. Rozhko, D. (2009), "Theory and problems of determination of essence of budget", Visnyk Kyivskoho natsionalnoho universytetu imeni Tarasa Shevchenka. Seriia: Ekonomika, Iss. 110, pp. 54-56.

9. Tulai, O.I. (2016), Derzhavni finansy i stalyi liudskyi rozvytok: kontseptualni dominanty ta dialektychna yednist [Public finances and sustainable human development: conceptual dominant and dialectical unity], monograph, Ekonomichna dumka, Ternopil, Ukraine, $414 \mathrm{p}$.

10. Shynkaruk, V.I. (Ed.) (2002), Filosofskyi entsyklopedychnyi slovnyk [Philosophical encyclopedic dictionary], Abrys, Kyiv, Ukraine, 751 p.

11. Yurii, S.I., Alekseienko, L.M., Demianyshyn, V.H. et al. (2012), Finansy [Finance], $2^{\text {nd }}$ ed., Znannia, Kyiv, Ukraine, 687 p. 